\title{
2 成分混合蒸気の分縮に関する解析
}

\author{
宗 像健・本田克美 \\ 九州大学工学部 化学機械工学科 ${ }^{\dagger}$
}

\begin{abstract}
2 成分混合蒸気の分縮操作に関し, 二重境膜説に基づいて分縮器内の気液の組成とその場所の凝縮 液流量と関連づけて解析した．その結果は既往のものに比べて分縮器内の諸量と位置との関連などの 点で理解しやすくなっている。 また，気液平衡関係が直線で表せる場合に対して，パラメータとして 気液両相の抵抗比打よび凝縮速度と総括物質移動係数の比を含む解を得た.ささに Rayleigh の関係 および気液両側の抵抗が無視できる場合をこの解の特別な場合として関係づけた。

分縮器内の操作線について，既往のいくつかの方法による計算結果と比較検討した
\end{abstract}

\section{緒言}

混合蒸気の分縮器の設計法を意図した研究には，その 最初のものとして著名な Colburn と Drew ${ }^{3)}$ ののの 後に Hochgesand ${ }^{5)}$ および Begemann ${ }^{1)}$ のものがある. Colburn $5^{3)}$ は二重境膜説に基づき，凝縮により生ずる 物質の流束を考慮したいわゆる高物質流束を伴う物質移 動の基礎となる関係式を導いて，混合蒸気から凝縮する 液の組成が凝縮速度の大小によって変化することを定量 的に示した点で画期的である. しかし，これを分縮器の 設計に応用する際に，蒸気側物質移動抵抗に加兄て液側 抵抗を考慮すれば問題が複雑になることを指摘するとと もに, 分縮器内を蒸気が通過するにつれて蒸気流量特よ び組成が変化することを考慮して解析することは困難で あるとして，逐次計算の方針を述べるにとどめている. 化学工学便覧7でもこの方針に従って記述されている. Hochgesand $^{55}$ および Begemann ${ }^{11}$ はいずれも2 成分系 の精留において, 精留塔本体を冷却した場合の操作で還 流量をぜロに近づけた極限が分縮器に相当するといら見 地から気液両側の物質移動抵抗を考慮して解析している が, 分縮器内の任意の位置に打汗る蒸気の組成 $y$ と液の 組成 $x$ のみを変数としてこれらの関係を追跡している 点, Begemann の解析には後述する不必要な仮定が含 まれている点,およびこれらの研究では最終的には実測 值から物質移動係数を逆算して整理しているため解析法 を設計に応用するには多くの考察を要する点など難点が ある。

本報での解析は, 以上の研究の延長線上に位置するも のではあるが， $x$ 抢よび $y$ を凝縮液流量 (無次元化し $r$ で表す）と結びつけて解析しているところに特徵があ り, これによって分縮器内の位置との関連やその他の点 でかなり理解しやすくなっていると思う。

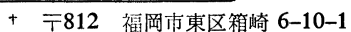

なお，高物質流束を伴う物質移動現象において，これ を境膜説に適用した結果が浸透説や境界層理論に適用し た結果とほとんど一致することは Bird らによって示 されているまた，著者らは濡れ壁塔での㠜縮を伴う精 留実験結果の整理において蒸気流が層流の場合の実測值 に対しても境膜モデルによってょく説明できることを認 め, このモデルがこの種の現象の特徵をよく表現すると 推論している ${ }^{6)}$.

また，混合蒸気の凝縮を解析する別の流れとして，二 相境界層理論を用いた研究4,8,8)も少なくないが，そこで は凝縮による蒸気本体の組成の变化を関心の対象として いない点と分縮操作としては有利である重力利用の向流 操作ではなくて並流操作が扱われている点で本報告の所 論と直ちには結びつけにくい。

\section{1. 理 論解析}

\section{$1 \cdot 1$ 向流分縮の場合}

1）物質収支関係式 Fig. 1 亿示す向流分縮器に おいて物質収支をとれば, まず分縮器全体に着目して全 量および低沸点成分について

$$
\begin{aligned}
& V_{\text {in }}=V_{\text {out }}+L_{\text {out }} \\
& V_{\text {in }} y_{\text {in }}=V_{\text {out }} y_{\text {out }}+L_{\text {out }} x_{\text {out }}
\end{aligned}
$$

また任意の位置より上部に着目すれば

$$
\begin{aligned}
& V=V_{\text {out }}+L \\
& V y=V_{\text {out }} y_{\text {out }}+L x
\end{aligned}
$$

となり,ここで

$$
\begin{aligned}
R & =L_{\text {out }} / V_{\text {out }} \\
r & =L / V_{\text {out }}
\end{aligned}
$$

を定義すれば，Eqs. (1)，(2) より

$$
(R+1) y_{\mathrm{in}}=y_{\mathrm{out}}+R x_{\mathrm{out}}
$$

Eqs. (3), (4)より

$$
(r+1) y=y_{\text {out }}+r x
$$

となる. 次に, Fig. 2 の微小区間に着目すれば 


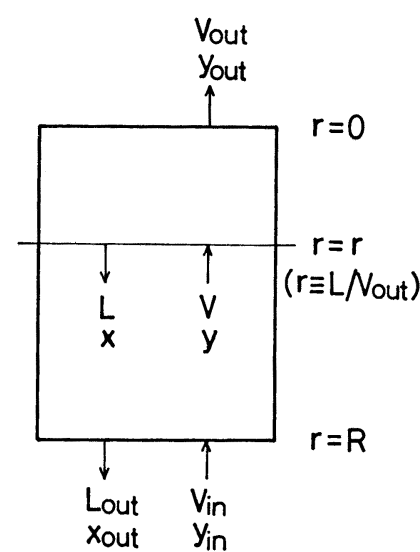

Fig. 1 Illustrative diagram of partial condenser (counter current flow)

$$
\begin{aligned}
& d V=d L \\
& d(V y)=d(L x)=x_{\mathrm{c}} d L
\end{aligned}
$$

が得られる．ここで $x_{c}$ はこの区間で凝縮する液の組成 で, 後の Eq. (13) で与えられる.

2) 凝縮過程の関係式 Fig. 3 に示寸二重境膜モ デルに対し，まず蒸気側に着目して低沸点成分 (A成分) の境膜内での $z$ の負方向への移動速度を書けば

$$
N_{\mathrm{A}}=c D_{v} \frac{\partial y}{\partial z}+N y
$$

となりこれを境膜にわたって積分すれば

$$
\frac{1}{N} \ln \frac{y-x_{c}}{y_{i}-x_{\mathrm{c}}}=-\frac{\delta_{v}}{c D_{v}} \equiv-\frac{1}{k_{y}}
$$

が得られる*.ただし， $x_{c}$ は

$$
x_{c}=N_{\mathrm{A}} / N
$$

であり， $k_{y}$ は蒸気側境膜物質移動係数である．Eq.(12) を書きかえると次式が得られる。

$$
x_{c}=y-\frac{y_{i}-y}{\exp \left(N / k_{y}\right)-1}
$$

次に液側に着目して同様の手順を用いれば Eq. (14) に 相当する式は

$$
x_{c}=x_{i}-\frac{x-x_{i}}{\exp \left(N / k_{x}\right)-1}
$$

となる。

3) 濃度分布の計算式 Eq. (10) に Eqs. (6), (9), (14)，(15) を入れると $x$ 拈よび $y$ に対してそれぞれ

$$
\begin{aligned}
& \frac{d x}{d r}=-\frac{1}{r} \cdot \frac{\exp \left(N / k_{x}\right)}{\exp \left(N / k_{x}\right)-1}\left(x-x_{i}\right) \\
& \frac{d y}{d r}=-\frac{1}{r+1} \cdot \frac{1}{\exp \left(N / k_{y}\right)-1}\left(y_{i}-y\right)
\end{aligned}
$$

となる.これらの式の解を得ようとするには $x_{i}$ を $x$ と $r$ のみで, $y_{i}$ を $y$ と $r$ のみで表せばよい。そそのため

* 境膜説では, 境膜厚さ $\left(\delta_{v}, \delta_{c}\right)$ は $N$ に依存しないと仮定される 2$)$. このことより $\delta_{v} / c D_{v}$ は $N=0$ のときの物質移動保数 $k_{y}$ となる。 ま た，液側についても蒸気側と同様のことがいえる。

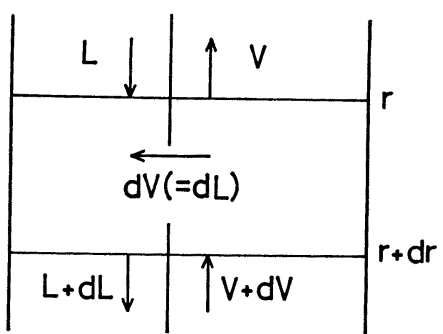

Fig. 2 Illustrative diagram for mass balance

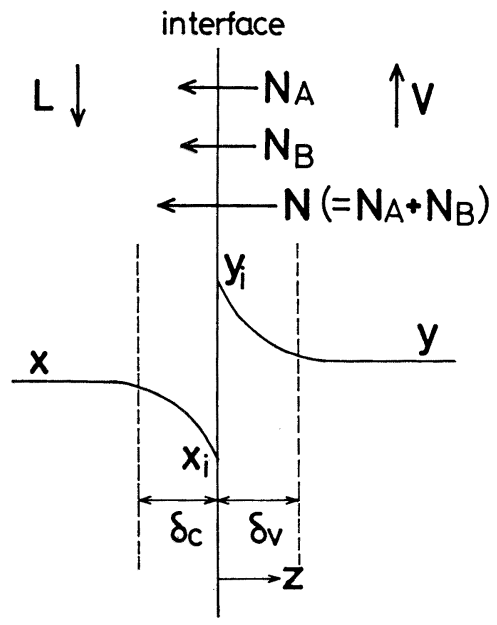

Fig. 3 Physical model of mass transfer

には Eq. (14) と Eq. (15) を等置した上で， $y_{i}$ または $x_{i}$ を平衡関係を用いて消去し， $y$ または $x$ を物質収支 の Eq. (8) を用いて消去すればょい. Eqs. (16)，(17) は, $N$ や $k_{x}, k_{y}$ が分縮器内の場所によって変化する場 合でも使用できる．ただし後述するように，これらの式 では $r=0$ は特異点となるので注意を要する.

4) 平衡関係が直線で表される場合 平衡関係が

$$
y=m x+b
$$

と表せるとして

$$
\begin{gathered}
\frac{1}{k_{y}}+\frac{m}{k_{x}} \equiv \frac{1}{K_{y}} \\
\left(\frac{1}{k_{y}}\right) /\left(\frac{1}{K_{y}}\right) \equiv \xi
\end{gathered}
$$

と定義することとする. Eq. (19) の $K_{y}$ は， $N=0$ の場 合には総括物質移動係数を表し，Eq. (20)の ときの蒸気側抵抗の割合を表すことになる． $N \neq 0$ の場 合にもこれら $K_{y}, \xi$ をパラメータとして用いることと すれば，Eqs. (16), (17) に含まれる量を

$$
\begin{gathered}
\frac{1}{\exp \left(N / k_{x}\right)-1}=\frac{1}{\exp \left\{(1-\xi) N /\left(m K_{y}\right)\right\}-1} \equiv A \\
\frac{1}{\exp \left(N / k_{y}\right)-1}=\frac{1}{\exp \left(\xi N / K_{y}\right)-1} \equiv B
\end{gathered}
$$

と置いて，前述の手順により $x_{i}$ を $x, y_{i}$ を $y$ で表し て Eqs. (16)，(17) に入れると次のようになる. 


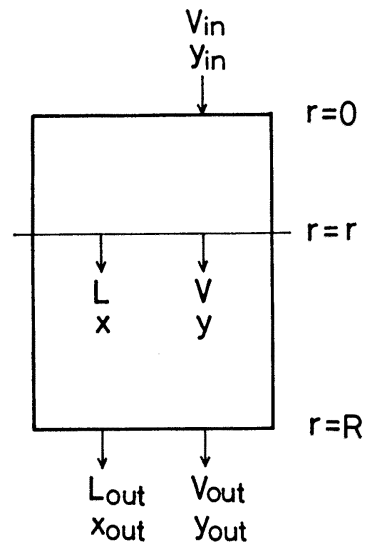

Fig. 4 Illustrative diagram of partial condenser (cocurrent flow)

$$
\begin{gathered}
\frac{d x}{d r}=-\frac{1}{r} \cdot \frac{1+A}{1+A+B m}\left[\left\{(1+B m)-(1+B) \frac{r}{r+1}\right\} x\right. \\
\left.+\left\{B \cdot b-(1+B) y_{\mathrm{out}} /(r+1)\right\}\right] \\
\frac{d y}{d r}=-\frac{1}{r} \cdot \frac{B}{1+A+B m}\left[\left\{A m-(1+A-m) \frac{r}{r+1}\right\} y\right. \\
\left.+\left\{(1+A) b \frac{r}{r+1}-A m \frac{y_{\mathrm{out}}}{r+1}\right\}\right]
\end{gathered}
$$

さらに $A, B$ が定数 $\left(N / k_{x}, N / k_{y}\right.$ が $r$ にってて変化し ない場合で Hochgesand ${ }^{5)}$ の計算過程に相当する) であ るならば, 次の解が得られる.

$$
\begin{array}{r}
x=\frac{(r+1)^{\beta+1}}{r^{\alpha+1}} \cdot \frac{1+A}{1+A+B m} \int_{0}^{r}\left\{-B \cdot b \frac{r^{\alpha}}{(r+1)^{\beta+1}}\right. \\
\left.+(1+B) y_{\text {out }} \frac{r^{\alpha}}{(r+1)^{\beta+2}}\right\} d r \\
y=\frac{y_{\text {out }}}{r+1}+\frac{(r+1)^{\beta}}{r^{\alpha}} \int_{0}^{r}\left\{-\frac{\alpha b(1+A)}{A m} \cdot \frac{r^{\alpha}}{(r+1)^{\beta+1}}\right. \\
\left.+(1+\beta) y_{\text {out }} \cdot \frac{r^{\alpha}}{(r+1)^{\beta+2}}\right\} d r
\end{array}
$$

ただし

$$
\begin{aligned}
& \alpha=A B m /(1+A+B m) \\
& \beta=B(1+A-m) /(1+A+B m)
\end{aligned}
$$

$x_{\text {out }}, y_{\text {in }}$ は Eqs. (25), (26) に扎いて $r=R$ と打けば得 られるが， $y_{\text {in }}$ と $R$ を与えて $x_{\text {out }}, y_{\text {out }}$ を求めるには Eq. (26) で $r=R$ で $y=y_{\text {in }}$ と打いた式を書きかえて

$$
y_{\text {out }}=\frac{y_{\text {in }}+\frac{\alpha b(1+A)}{A m} \cdot \frac{(R+1)^{\beta}}{R^{\alpha}} \int_{0}^{R} \frac{r^{\alpha}}{(r+1)^{\beta+1}} d r}{\frac{1}{R+1}+(1+\beta) \frac{(R+1)^{\beta}}{R^{\alpha}} \int_{0}^{R} \frac{r^{\alpha}}{(r+1)^{\beta+2}} d r}
$$

により $y_{\text {out }}$ を求め， $x_{\text {out }}$ は Eq. (7) を用いて求めれば よい.また， $r=0$ では Eqs. (25), (26) の極限值を求め ることにより次式が得られる.

$$
\begin{aligned}
& (x)_{r=0}=\left\{-B b+(1+B) y_{\text {out }}\right\} /(1+B m) \\
& (y)_{r=0}=y_{\text {out }}
\end{aligned}
$$

なお, Eq. (30) の結果は, $(d y / d x)_{r=0}$ が有限值として存
在するための条件（後出の Eq. (42) 参照) から Hochgesand $^{5)}$ が与えている $(x)_{r=0}$ の值

$$
(x)_{r=0}=y_{\text {out }}-B\left\{\left(y^{*}\right)_{r=0}-y_{\text {out }}\right\}
$$

と一致する.

また, $r=0$ では Eqs. (23), (24) からは $d x / d r, d y / d r$ は評価できないが，Eqs. (25), (26) で $r \rightarrow 0$ の極限を考 えることにより

$$
\begin{aligned}
&\left(\frac{d x}{d r}\right)_{r=0}=\frac{B(1+A)(1+B)}{2+2 A+2 B m+A B m} \cdot \frac{1}{1+B m}\{(1- \\
&\left.m) y_{\text {out }}-b\right\} \\
&\left(\frac{d y}{d r_{i t}}\right)_{r=0}=\frac{B}{1+B m}\left\{(1-m) y_{\text {out }}-b\right\}
\end{aligned}
$$

が求められる.これらを用いると

$$
\left(\frac{d y}{d x}\right)_{r=0}=\frac{2+2 A+2 B m+A B m}{(1+A)(1+B)}
$$

となるが, これは $m=1$ で $A, B$ が特殊な值を持つ場 合のいくつかの例に対して Hochgesand ${ }^{5)}$ が得ている解 に当てはめてみると妥当な值を与えることが確かめられ る. また, $N, k_{x}, k_{y}$ が $r$ によって変化する場合には, Eq. (30) は $r=0$ に拈けるそれらの值を用いれば成り立 つが, Eqs. (33), (34), (35) は使用できない.それは $r=0$ のこれらの量の微分值が関係してくるからで,

Appendix に蒸気側抵抗支配の場合について示寸.

\section{$1 \cdot 2$ 並流分縮の場合}

並流では Fig. 4 のようになり, 向流の場合と類似な 方法で諸式が導けるが，ここには結果のみを示す.

$$
\begin{gathered}
y_{\mathrm{out}}=y_{\mathrm{in}}(R+1)\left\{1-\frac{1+\beta}{R^{\alpha}} \int_{0}^{R} \frac{r^{\alpha}}{(R+1-r)^{\beta+2}} d r\right\} \\
+\frac{\alpha b(1+A)}{A m R^{\alpha}} \int_{0}^{R} \frac{r^{\alpha}}{(R+1-r)^{\beta+1}} d r \\
(x)_{r=0}=\left\{-B b+(1+B) y_{\mathrm{in}}\right\} /(1+B m) \\
\left(\frac{d y}{d x}\right)_{r=0}=\frac{2+2 A+2 B m+A B m}{(1+A)(1+B)}
\end{gathered}
$$

Eq. (37) おょび Eq. (38) は向流における Eqs. (30), (35) と同じである.

\section{2. 数值計算例}

計算例としては Hochgesand ${ }^{5)}$, Begemann ${ }^{1)}$ が扱っ ている $n$-ヘキサン〜ベンゼン系 (平衡関係は $0.5<x<$ 0.73 では $y=0.779 x+0.189)$ について示す.

\section{2・1 $\boldsymbol{y}_{\text {out }}-\boldsymbol{y}_{\text {in }}$ の值}

パラメータとしては $N / K_{y}, \xi, R$ がある. Figs. 5, 6 には $y_{\mathrm{in}}=0.5735$ (この值は Begemann の論文中 ${ }^{1)}$ の Bild35a から引用した) で $\xi=1(A=\infty$, すなわち蒸気側 抵抗支配）について, 横軸に $R$ をとり $N / K_{y}$ をパラメ 一タとしてそれぞれ向流と並流に拈ける結果を示してい る. ここで $y_{\text {out }}$ は Eq. (29) あるいは Eq. (36) を数 值積分して求めた. 図中, Rayleigh とあるのは本解析 


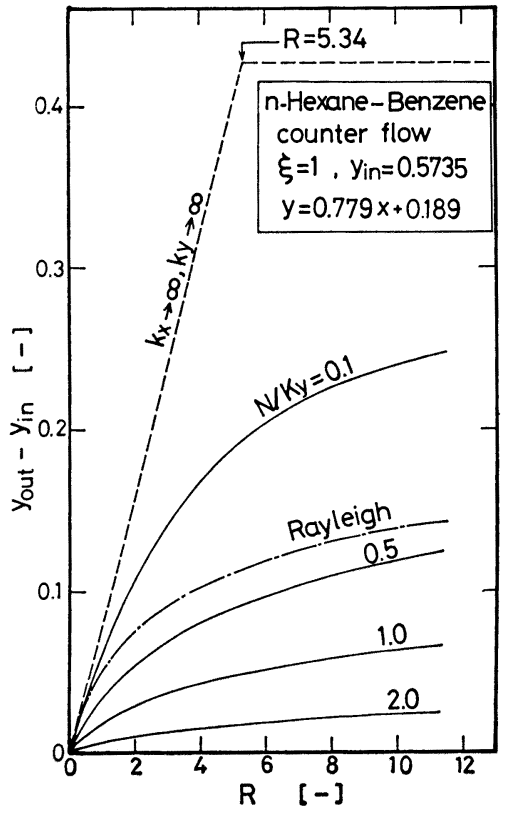

Fig. 5 Relation between $y_{\text {out }}-y_{\text {in }}$ and $R$ (counter current flow)

で $k_{y} \rightarrow \infty, k_{x} \rightarrow 0$ とおけば得られるもので, 向流, 並流 ともに同じ結果となる. 平衡関係が Eq. (18) で表され るときは

$$
y_{\text {out }}=\frac{1}{m-1}\left[\left\{(m-1) y_{\text {in }}+b\right\}(R+1)^{(m-1) / m}-b\right]
$$

となる。

$k_{x} \rightarrow \infty, k_{y} \rightarrow \infty$ と記した線は, 液側, 蒸気側ともに物 質移動抵抗がない場合で, 向流拉よび並流飞対してそれ ぞれ $y_{\text {out }}-y_{\text {in }}$ の最大値を与えている.ここで, 向流の ときは $x_{\text {out }}$ は $y_{\text {in }}$ に平衡な液組成 $x_{1 \mathrm{n}}$ *であることに なるが，それが満足されるのは Eq. (7) より $R \leqq(1-$ $\left.y_{\mathrm{in}}\right) /\left(y_{\mathrm{in}}-x_{\mathrm{in}} *\right)$ の範囲飞扎いてであり, これ以上の $R$ では $y_{\text {out }}=1$ であるから， $x_{\text {out }}=y_{\mathrm{in}}-\left(1-y_{\mathrm{in}}\right) / R$ となっ て $x_{\mathrm{in}}{ }^{*}$ より大きい值となる. 平衡関係が Eq. (18) で 表されるときは

$y_{\text {out }}-y_{\text {in }}=\left\{(m-1) y_{\text {in }}+b\right\}(R / m) \quad$ （ただし $\left.y_{\text {out }} \leqq 1\right)$

となる．並流の場合は， $x_{\text {out }}$ は $y_{\text {out }}$ に平衡な組成とな るから平衡分縮に活かならない，平衡関保が Eq. (18) で表されるならば

$$
y_{\mathrm{out}}-y_{\mathrm{in}}=\left\{(m-1) y_{\mathrm{in}}+b\right\} R /(m+R)
$$

である.

その他の線をみると向流，並流ともに $N / K_{y}$ の増加 とともに $y_{\text {out }}-y_{\text {in }}$ は減少しており感覚的にも妥当な結 果となっている，また向流で $N / K_{y}$ が小さいところで は， Rayleigh の值よりも大きな值を与えることもわか る.

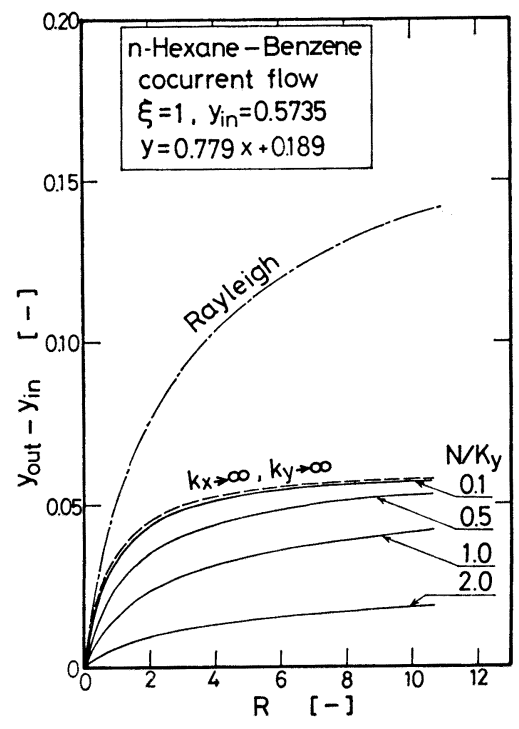

Fig. 6 Relation between $y_{\mathrm{out}}-y_{\mathrm{in}}$ and $R$ (cocurrent flow)

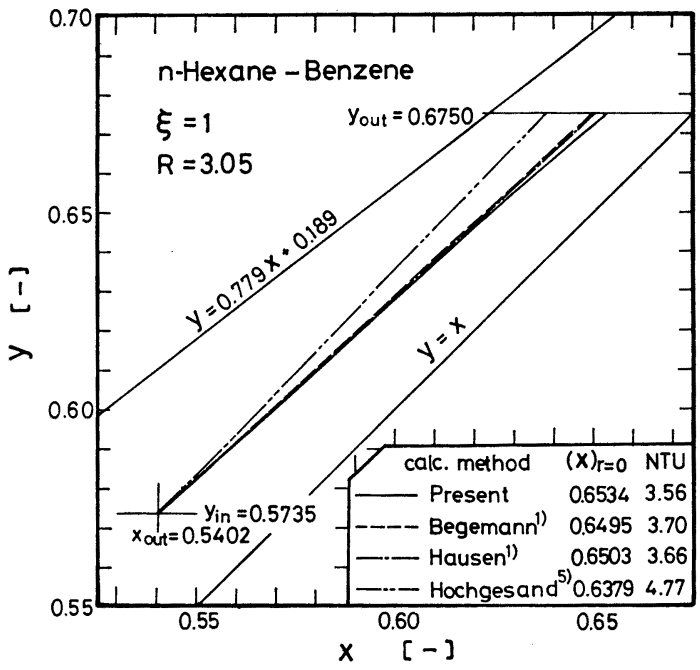

Fig. 7 Comparison of operating lines calculated from a few different methods

\section{$2 \cdot 2$ 操作線}

解析法による操作線の相違を調べるために, ここでも Begemann の論文中 ${ }^{1)} の$ Bild 35a を引用することとす る. この図は, 前述の平衡関係の範团に拈ける向流操作 で $y_{\text {in }}=0.5735, R=3.05, y_{\text {out }}=0.6750, x_{\text {out }}=0.5402$ という実験結果に対する操作線を示した図であり, 蒸気 側抵抗支配のもとでの Hochgesand の方法, Hausen の方法および Begemann の方法によるもののほか，む ら一つの方法による結果が示されている.ここでは前三 者に対して確認するとともに，本論文の方法によって計 算した操作線を示すこととする. 
まず, Hochgesand の方法は, 操作線の傾きを表す次 式を $N / K_{y}$ 一定のもとに分縮器の全長にわたって数值 積分を行い，両端組成を満たすような $K_{y}$ を見出すもの である. ${ }^{\dagger}$

$\frac{d y}{d x}=\frac{y_{\text {out }}-y}{y_{\text {out }}-x} \cdot \frac{1}{1-\frac{y-x}{y^{*}-y}\left\{\exp \left(N / K_{y}\right)-1\right\}}$

Eq. (42) を物質収支の関係を用いて変形すれば

$\mathrm{NTU} \equiv \int_{y_{\text {in }}}^{y_{\text {out }}} \frac{d y}{y^{*}-y}=-\int_{V_{\text {in }}}^{V_{\text {out }}} \frac{d V}{V\left\{\exp \left(N / K_{y}\right)-1\right\}}$

となるので， $N / K_{y}$ が一定であれば右辺は積分できて

$$
\mathrm{NTU}=\frac{\ln (1+R)}{\exp \left(N / K_{y}\right)-1}
$$

となる. Hochgesand は $K_{y}$ を求める繰り返し計算に この関係を利用している.

Hausen の方法は, Begemann の論文中に述べてある が, この方法では, 平衡線と操作線との差は液組成と直 線関係にあり，また上端からある位置までの移動単位数 はその位置の凝縮液流量に比例するといら二つの仮定を おいている. まず，第 1 の仮定は

$$
y^{*}-y=A^{*} x+B^{*}
$$

と表されるので, Eq. (43) の左辺の NTU は平衡関係 が Eq. (18) で表されるときには積分できて次式で与え られる。

$$
\mathrm{NTU}=\frac{m-A^{*}}{A^{*}} \ln \left(\frac{y_{\text {out }}{ }^{*}-y_{\text {out }}}{y_{\mathrm{in}_{\mathrm{n}}}{ }^{*}-y_{\mathrm{in}}}\right)
$$

ただし

$$
A^{*}=\frac{\left(y_{\text {out }} *-y_{\text {out }}\right)-\left(y_{\text {in }} *-y_{\text {in }}\right)}{(x)_{r=0}-x_{\text {out }}}
$$

また， $(x)_{r=0}$ の値は第 2 の仮定より次のように与えられ る.すなわち, この仮定は

$$
\left(\frac{d y}{y^{*}-y}\right) / d L=-\frac{\mathrm{NTU}}{L_{\mathrm{out}}}
$$

と表され，これに Eqs. (9)，(10) の物質収支の関係を入 れて分縮器上端 $(r=0)$ に適用すれば次式が得られる.

$$
(x)_{r=0}=y_{\text {out }}-\left(y_{\text {out }} *-y_{\text {out }}\right) \mathrm{NTU} / R
$$

Hausen の方法では, 本例題のように平衡関係が直線で 表される場合には Eq. (46) と Eq. (48) を連立させて $(x)_{r=0}$ と NTU の值を求めることに帰し, また操作線 も当然直線で表されることになる.

† Eq. (42)は Hochgesand が導いた操作線を表す式であるが, Eq. (24)を Eq. (23) で辺々割り Eqs. (8), (18) の関係を用いても得ら れる.なお， $r=0$ における液組成は Eq. (30) より計算できる。

†+ Begemann の方法では, $K_{y}$ は次のょうに表される.

$$
K_{y}=K_{y_{\text {in }}}-\frac{K_{y_{\text {in }}}-K_{y_{\text {out }}}}{\mathrm{NTU}} \int_{y_{\text {in }}}^{y} \frac{d y}{y^{*}-y}
$$

ここで, 分縮器の両端での $K_{y}$ の最初の仮定值は, そこでの蒸気流 量に対する断熱精留実験結果 $\left(K_{y} \propto V 0.8\right.$ の形で表される)より算定 されるが，Eq. (43) の関係が満たされるょうな $K_{y}$ を見出すため には, 両端における $K_{y}$ の值として最初の仮定值に同し比率をかけ て探索している。
Begemann の方法では, Hochgesand の方法と同様 に Eq. (42) の数值積分と同時に Eq. (43) の両辺を計 算し，これらが等しくなるような $K_{y}$ を求めるのである が， $K_{y}$ を蒸気流量 $(V)$ の一次関数とおき, しかもこの $V$ を上述の Hausen の第 2 の仮定を用いて関係づて いる††. しかし，この仮定は物質収支と一致するもので はなく，また解析の上で必要なものでもない.

すなわち, Appendix の Eq. (A-1) において $K_{0}=$ $K_{y_{\text {out }}}, K_{1}=\left(K_{y_{\text {in }}}-K_{y_{\text {out }}}\right) / R$ とおいて Eqs. (23), (24) の数值積分を行えば $x$ と $y$ の関係を表す操作線は得ら れるのである，あるいは，物質収支を表す Eqs. (3)，(4) より

$$
V=V_{\text {out }}\left(y_{\text {out }}-x\right) /(y-x)
$$

として $V$ は $x$ と $y$ で表されるから，これを Appendix の Eq. (A-1) に入れると $K_{y}$ は次式で表されることに なる.

$$
K_{y}=\frac{K_{0}(y-x)+K_{1}\left(y_{\text {out }}-y\right)}{y-x}
$$

これを用いて Eq. (42) を数值積分すれば操作線が得ら れる. そして両端組成を満足するような $K_{y}$ を繰り返し 計算により求めることができる.なお，ここでの計算例 としては, $K_{0}=K_{1}$ すなわち $K_{y}$ が $V$ に比例する場合 を示す.

Fig. 7 は, 以上の諸計算法により得られた結果を示 したものである. Hochgesand の方法においては $N / K_{y}$ $=0.2571$ といら結果が得られ, Begemann が計算して いる結果とよく一致した. なお, Hochgesand の方法で は Eq. (42) の数值積分だけでなく, Eqs. (25), (26) の 計算も行い, これらの結果が一致することを確かめた. また, Begemann と Hausen の方法による結果にはほ とんど差がなく，これらの線も Begemann が計算して いる結果とほとんど一致している. しかし，Begemann の方法では Eq. (43) の関係を満たすときの $r=0$ にお ける $x$ の值は, Eq. (30) より得られる值とは一致しな かった. これは前述の不必要な仮定が含まれているため である. 一方, Eq. (50)を用いた本論文の方法による結 果は, Begemann の方法によるものとそれほど差はな いが, Eq. (43), Eq. (30) のほか Eq. (A-7) を同時に 満足した。

Fig. 7 によれば， $N / K_{y}$ を一定とした Hochgesand の線が最も上に位置し, NTU の值としてもそれ以外の ものよりかなり大きい. 一方, Hausen の方法は直観的 な仮定を用いており, 計算も最も簡単ではあるが，その 結果は $K_{y}$ が $V$ に比例すると仮定した本論文の方法に よる結果とほぼ一致しており, 分縮器内の組成変化を知 る近似的な方法としてはかなり有効なものと考えられ る. 


\section{結}

2 成分混合蒸気の分縮操作に関し, 二重境膜説に基づ いて解析を行い, 分縮器内の気液の組成とその場所の凝 縮液流量の関係を与える微分方程式を導いた。 また，気 液平衡関係が直線で表される場合についてその解を導い た. それは, 気液平衡関係 $(m$ と $b)$, 気液両相の抵抗比

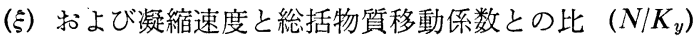
をパラメータとして与えられる. さらに Rayleigh の関 係および気液両側の抵抗が無視できる場合をこの解の特 別な場合として関連づけた。

計算例として, 向流および並流について点気出口濃度 と還流比との関係を示す数値計算結果を図示するととも に, 分縮器内の操作線について既往のいくつかの方法に よる計算結果と比較検討した。

\section{Appendix}

ここには例として $N$ を一定とし, 蒸気側抵抗支配 $(A=\infty$ で $\xi=1)$ で $k_{y}\left(=K_{y}\right)$ が $r$ の一次式で表され る場合 (Begemannの計算過程に対応する) について述 ベる.このとき

$$
K_{y}=K_{0}+K_{1} \cdot r
$$

と抬けば，塔頂近傍 $(r \rightarrow 0)$ では

$$
B=B_{0}\left(1+B_{1} \cdot r\right)
$$

ただし

$$
\begin{gathered}
B_{0}=1 /\left\{\exp \left(N / K_{0}\right)-1\right\} \\
B_{1}=B_{0}\left(N / K_{0}\right)\left(K_{1} / K_{0}\right) \exp \left(N / K_{0}\right)
\end{gathered}
$$

となり，この関係を Eqs. (23)，(24) に入れて積分し， $r \rightarrow 0$ の極限を考えることにより次の関係が得られる.

$$
\begin{aligned}
&\left(\frac{d x}{d r}\right)_{r=0}=\frac{B_{0}\left(1+B_{0}+B_{1}\right)}{\left(1+B_{0} m\right)\left(2+B_{0} m\right)}\left\{(1-m) y_{\text {out }}-b\right\} \\
&\left(\frac{d y}{d r}\right)_{r=0}=\frac{B_{0}}{1+B_{0} m}\left\{(1-m) y_{\text {out }}-b\right\} \\
&\left(\frac{d y}{d x}\right)_{r=0}=\frac{2+B_{0} m}{1+B_{0}+B_{1}}
\end{aligned}
$$

な抢， $K_{y}$ が蒸気流量 $(V)$ に比例するならば $K_{1}=K_{0}$ となる。また，Eq. (A-2) から Eq. (A-7) までの諸式 は $K_{y}$ が $r \rightarrow 0$ での極限として Eq. (A-1) で表される なら纺成り立つものである。

\section{Nomenclature}

$\begin{aligned} A, B= & \text { values defined by Eqs. (21) and (22) } \\ A^{*}, B^{*}= & \text { values defined by Eq. (45) } \\ B_{0}, B_{1}= & \text { values defined by Eqs. (A-3) and } \\ & (\text { A-4) } \\ b \quad= & \text { intercept of the equilibrium curve }\end{aligned}$

defined by Eq. (18)

$c \quad=$ molar density

$D_{v} \quad=$ diffusion coefficient

$K_{0}, K_{1}=$ values defined by Eq. (A-1)

$K_{y}=$ overall vapor-phase mass transfer $\left[\mathrm{mol} / \mathrm{cm}^{2} \cdot \mathrm{s}\right]$ coefficient

$\left[\mathrm{mol} / \mathrm{cm}^{2} \cdot \mathrm{s}\right]$

$k_{x}, k_{y}=$ liquid and vapor phase mass transfer coefficients

$\left[\mathrm{mol} / \mathrm{cm}^{2} \cdot \mathrm{s}\right]$

$L \quad=$ molar flow rate of condensate $\quad[\mathrm{mol} / \mathrm{s}]$

$m \quad=$ slope of the equilibrium curve defined by Eq. (18)

$N, N_{A}=$ mass fluxes of condensate and more volatile component

$\left[\mathrm{mol} / \mathrm{cm}^{2} \cdot \mathrm{s}\right]$

$R, r \quad=$ reflux ratios defined by Eqs. (5) and (6)

$V \quad=$ molar flow rate of vapor $[\mathrm{mol} / \mathrm{s}]$

$x, y=$ mole fractions of more volatile component in liquid and vapor phases

$z \quad=$ distance from interface

$\alpha, \beta=$ values defined by Eqs. (27) and (28) [-]

$\delta \quad=$ film thickness

[cm]

$\xi \quad=$ ratio of mass transfer resistances defined by Eq. (20)

$\langle$ Subscripts〉

$$
\begin{array}{ll}
c & =\text { condensate } \\
\boldsymbol{i} & =\text { interface } \\
v & =\text { vapor phase }
\end{array}
$$

$\langle$ Superscript $\rangle$

$* \quad=$ equilibrium

\section{Literature cited}

1) Begemann, E.: VDI-Forschungsheft 553, VDI-Verlag, Düsseldorf (1972)

2) Bird, R. B., W. E. Stewart and E. N. Lightfoot: "Transport Phenomena", p. 658, 675, Wiley, New York (1960)

3) Colburn, A. P. and T. B. Drew: Trans. AIChE, 33, 197 (1937)

4) Fujii, T. and Y. Kato: Trans. JSME, 46-402, 306 (1980)

5) Hochgesand, G.: VDI-Forschungsheft 498, VDI-Verlag, Düsseldorf (1963)

6) Honda, K., A. Matsuda and T. Munakata: Kagaku Kogaku Ronbunshu, 9, 37 (1983)

7) Kagaku Kogaku Kyokai (ed.): "Kagaku Kogaku Benran”, 4th ed., p. 320, Maruzen, Tokyo (1978)

8) Lucas, K.: Int. J. Heat Mass Transfer, 19, 1273 (1976)

9) Sparrow, E. M. and E. Marschall: Trans. ASME, C-91, 205 (1969)

(1985 年 2 月 28 日受理; 化学工学協会第 18 回秋季大会 (福岡, 1984 年 10 月) にて一部発表) 


\section{Analytical Study of Partial Condenser for Binary Vapor Mixture}

Tsuyoshi Munakata and Katsumi Honda

Dept. of Chem. Eng., Kyushu Univ., Fukuoka 812

Key Words: Condensation, Mass Transfer, Binary System, High Mass Flux, Partial Condensation, Two-Film Theory

A theoretical analysis of the partial condenser is proposed. Based on the two-film theory, its feature lies in expressing the vapor or liquid composition in the condenser related to the local flow rate of condensate. The results are more comprehensive for use in design calculation than are those of previous investigators, since the position in the condenser can be related and other there are analytical advantages. For the case of the linear equilibrium relation, the solution is given with two parameters: the mass transfer resistance ratio of liquid to vapor phases and the ratio of the condensation flux to the overall mass transfer coefficient. The well-known Rayleigh solution and another extreme case where the mass transfer resistances in both the liquid and vapor phases vanish are explained in relation to the solutions.

A numerical example on the operating line in a partial condenser is shown. The present method gives reasonable results compared with the few other methods. 